\title{
Fundamentalism as a key topic for religious education. Observations from a Protestant perspective ${ }^{1}$
}

\author{
Martin Rothgangel
}

The origins of religious fundamentalism lie not in Islam, but in Christianity. Specifically, the "original" religious fundamentalism may be found in the Protestant tradition of the United States. Since studying the concept's origin will exemplify the basic features of fundamentalism, the first part of this article is devoted to an overview of this topic. Against this backdrop, the second part will present fundamentalism as a theological challenge, according special attention to the inerrancy of Scripture. In the third and final part, conclusions are drawn from a religious educational perspective: the educational relevance of fundamentalism is pedagogically justified, reflexive questions are provided for religious teachers, and finally, the reasons for why fundamentalism is a key topic for religious education are thetically summarized.

Martin Rothgangel is Professor of Religious Education and Dean of the Faculty of Protestant Theology at the University of Vienna. His main research areas are: competencies and standards in religious education, empirical research in religious education, interreligious learning, and religious education at schools in Europe.

\section{Introduction}

The term "fundamentalism" has surged in popularity since at least the early 1980s: it is most frequently used to refer to Muslim fundamentalists, though in Germany, it also finds usage in reference to the "Green fundis" who oppose the "realists" within the Green Party. A consequence of such inflationary usage is an imprecise notion of what fundamentalism actually means. Furthermore, the word's frequent usage as a shibboleth to belittle others has in part given rise to a trend in scholarship "that avoids the concept or rejects it explicitly" . A pointed objection to this is the observation that "if one wishes, as a scholar, to objectively influence public discourse, one should not isolate oneself by rejecting certain language"3.

When one speaks of "fundamentalism" today, Islamic fundamentalism inevitably looms in the foreground of the discussion. In this very issue on "Religious Fundamentalism", this aspect of fundamentalism has already received wide at-

1 The present article is the revised, updated and translated version of Rothgangel 2010.

2 Riesebrodt 2005.

3 Ibid., p. 15. 
tention; this is positive in my view, particularly in that Muslims are themselves addressing this issue. Indeed, it is precisely because fundamentalism is so frequently used as a shibboleth to belittle others that I wish to deliberately direct attention to this concept's Protestant tradition. In doing so, we arrive at a perhaps surprising finding: the origins of religious fundamentalism lie not in Islam, but in Christianity. Specifically, the "original" religious fundamentalism may be found in the Protestant tradition of the United States. Since studying the concept's origin will exemplify the basic features of fundamentalism, the first part of this article is devoted to an overview of this topic. Against this backdrop, the second part will present fundamentalism as a theological challenge, according special attention to the inerrancy of Scripture. In the third and final part, conclusions are drawn from a religious educational perspective: the educational relevance of fundamentalism is pedagogically justified, reflexive questions are provided for religious teachers, and finally, the reasons for why fundamentalism is a key topic for religious education are thetically summarized.

\section{Basic features of Protestant fundamentalism}

\subsection{Origins of fundamentalism in the United States}

Fundamentalism arose from the evangelical movement in the United States. Like the evangelical movement, fundamentalism is not tied to any particular religious denomination, such as Presbyterian or Baptist. The term "fundamentalism" most likely originates from The Fundamentals: A Testimony To The Truth, a twelvevolume collection of essays published between 1910 and 1915. The ensuing movement is characterized by five fundamental points (Biblical inerrancy, the virgin birth of Christ, substitutionary atonement, the bodily resurrection and second coming of Christ, and the historical authenticity of the miracle), which were adopted in 1910 by the Presbyterian General Assembly in order to regulate admissions to the Union Theological Seminary in New York. ${ }^{4}$ One should not, however, overestimate the importance of these five points: another important, fundamentalist statement of faith - the "Niagara Creed" of 1878 - contains not five, but fourteen fundamental points. One substantive difference is that point 13 of the "Niagara Creed" includes a millenarian doctrine. ${ }^{5}$ It is in no way fortuitous, however, that both the five Fundamental points and the first point of the "Niagara Creed" espouse a literalist doctrine of Biblical inspiration and consequently the inerrancy of Scripture.

This latter aspect, the dominant role of Biblical inerrancy, deserves a closer examination because it has been the chief attribute of Protestant fundamentalism

4 The five points in question may be found in Reich 1969, p. 263.

5 "Niagara Bible Conference", n. d. 
since its origins on through the present day. In order to determine a psychosocial reason for why fundamentalists espouse Biblical inerrancy so vigorously, it is worth reviewing the beginning of the fundamentalist movement in the United States. Contrary to popular belief, fundamentalism did not develop in the rural southern United States but "in the cities of the East Coast and in Chicago" ${ }^{\text {". In the }}$ second half of the $19^{\text {th }}$ and the beginning of the $20^{\text {th }}$ centuries, various symptoms of modernity fostered a growing sense of crisis. Concisely, at least the following aspects bear mentioning here:

(1) Industrialization and rapid urbanization: these led to the emergence of cultural pluralism, the questioning of traditional values and a dramatic change in social structure. In turn, fundamentalists viewed, for instance, the social and political advancement of women as a threat to patriarchal family structure - which alone corresponded to their view of the divine order. ${ }^{7}$

(2) The secularization and scientification of weltanschauung: in addition to the family, fundamentalists believed that the two traditional "guarantors of the Christian character of the American nation" were also at risk - religious denominations by liberal theology, and schools by the introduction of the teaching of evolution. ${ }^{8}$ Indeed, secularization happened so rapidly in this historically and deeply Protestant country that by the end of the 1920s, 12 of the 49 states had banned the Bible in their public schools. ${ }^{9}$

Fundamentalists saw Darwinism as an exemplary denial of Biblical truth and, as its consequence, the debasement of humans (as created in God's image) to apes. In The State of Tennessee v. John Thomas Scopes, the so-called "Scopes Monkey Trial", fundamentalist representatives won a Pyrrhic victory: although Thomas Scopes was ultimately sentenced to pay a fine for teaching the theory of evolution at a high school and although several other states subsequently banned the teaching of evolution in schools, Scopes' lawyer had managed splendidly to expose this fundamentalist concern to ridicule in the ensuing media circus. In the aftermath of this spectacular trial, fundamentalism was seen as "backward" and acquired a negative connotation - to the point that by the 1930s, fundamentalists had largely abandoned their sociopolitical activities. ${ }^{10}$

Examining this sociopolitical dispute about the theory of evolution, we can firstly observe that fundamentalists frequently prefer to operate on the political level, which draws the conclusion that the intersection between religion and

\footnotetext{
6 Geldbach 1995, p. 62.

7 Riesebrodt 1990, p. $116 \mathrm{f}$.

8 See ibid., p. 58.

9 Ibid., p. 119.

10 For the renaissance of fundamentalism in the United States and its present significance, see e. g. Brocker 2004, Victor 2005, Hochgeschwender 2007, Jewett / Wangerin 2008 .
} 
politics is an important point to an analysis of fundamentalism. ${ }^{11}$ At the same time, we should also note that fundamentalists do not necessarily act politically (let alone - as spectacular media coverage is intent on suggesting - violently) but that, to the opposite, there are also phases during which they operate in seclusion. Secondly, this dispute demonstrates a distinct feature of fundamentalism: the "modern" questioning of previous models of religious orientation and social structure. Fundamentalists react to "modern" insecurities with a regressive strategy: a return to the principles of divine order, verbally inspired and inerrantly documented in the Bible. Thus, in Biblical inerrancy fundamentalists find religious security in the face of an anomic modernity.

One thing should not be overlooked, however: this anti-modernism bears modern traits. In a subtle manner, their adopted strategy shows how rooted fundamentalists are in the popular scientific mindset of the $19^{\text {th }}$ century. Fundamentalists repeatedly speak of "facts". Only, these do not entail natural "facts", but Biblical "facts". And proceeding from these Biblical "facts", fundamentalists erect, among other things, a "scientific" counter-theory to evolution: creationism.

These observations about American fundamentalism confirm Jürgen Moltmann's view that fundamentalism does not concern itself with modernity per se, but only with those aspects of modernity that it finds threatening: "Fundamentalists do not respond to the crises of the modern world so much as to the crises that the modern world [...] provokes in their basic certitudes." ${ }^{12}$ In this sense, fundamentalists are prepared to adopt technological advances such as modern communications or findings from the social and natural sciences, as long as these do not put into question the Bible's timeless authority.

This shows that this is no blind anti-modernism [...prevailing, M. R.] here. To the fundamentalists, the issue here has much more to do with their 'foundation's' infallible and unqualified authority over scientific methods and results. Only in the case of conflict may it be said that the white wall is black, since divine authority has claimed it so, or that Jesus could not have had any siblings, since the dogma of his Virgin Mother precludes it. ${ }^{13}$

Accordingly, Gottfried Küenzlen goes so far as to characterize fundamentalism in general as a modern form of antimodernism. ${ }^{14}$ It is precisely in modern antimodernism that we may observe the same traits that fundamentalist movements share in general. A more detailed definition of this approach to fundamentalism can be made through the following characteristics:

\footnotetext{
11 For more detail, see Tibi 2008.

12 Moltmann 1992, p. 270.

13 Ibid.

14 Küenzlen 1991; 1992.
} 


\subsection{Characteristics of fundamentalist groups ${ }^{15}$}

The Fundamentalism Project - a comprehensive, international investigation involving over one hundred scholars, whose results were published in five main volumes under the direction of Marty \& Appleby (1991-1995) - examined a diversity of Christian, Islamic, Jewish, and isolated South Asian religious groups. This research base yielded five ideological (1-5) and four organizational characteristics (6-9) of fundamentalist groups: ${ }^{16}$

(1) Reactivity. Fundamentalists react to processes and consequences of secularization and modernity, which have penetrated the larger religious community.

Protestants, Catholics, Muslims, Jews, Hindus, and Sikhs are losing their members to the secular world outright, or to relativism [...] which leads, fundamentalists believe, to the same end: the erosion and displacement of true religion. Fundamentalism is a militant effort to counteract this trend. ${ }^{17}$

Given this "primary" feature, Grünschloß proposes a tentative, minimal definition of fundamentalism: "Fundamentalism justifies itself first and foremost as a modern, collective, religious response to the emergent effects or aspects of modernity [that it sees as, M. R.] 'dangerous' and tradition-corroding."18

(2) Selectivity. Fundamentalists reduce complexity by applying three different selection strategies, which are nevertheless closely linked: first, rather than seeking to conserve the religious tradition as a whole, fundamentalists declare particular elements of the tradition "fundamental" - frequently preferring those that evoke a clear differentiation to their respective "mainstream" (e.g. the apocalyptic tradition of the Book of Daniel and Johannine eschatology in the Protestant fundamentalism of the United States); second, fundamentalists selectively adopt aspects of modernity, accepting much of modern science and technology (e.g. email) or imitating theological and organizational aspects of cultures and religions that are perceived as threatening (this applies in particular to non-Abrahamic religions, such as in the instance of the Hindu adoption of missions); and third, fundamentalists pursue a selective opposition to certain consequences and processes of modernity, articulating them in a manner that transforms them into objects of resistance (e.g. tourism in Egypt, abortion clinics in the United States, "land for peace" in Israel).

15 I am here indebted to my former Göttingen colleague Andreas Grünschloß (2009, p. $186 \mathrm{ff}$.) for directing me to a differentiated reception of the findings of the fifth volume of the Fundamentalism Project (Marty / Appleby 1995).

16 For the following, see Marty / Appleby 1995, p. 405-408.

17 Ibid., p. 405.

18 Grünschloß 2009, p. 187. 
(3) Moral Manichaeism. For fundamentalists, a Manichean worldview is fundamental - that is, the world is divided dualistically into a realm of light (a spiritual world of good) and into a realm of darkness (a material world of evil). In the end, good will triumph over evil.

(4) Absolutism and inerrancy. For fundamentalists, their own "Holy Text" (e.g. the Torah, the Bible, the Quran) is of divine origin and absolutely true in all its parts. This inerrancy may vary and be transferred to alternate "foundations" within the scriptural religions themselves (e.g. papal infallibility) but does so in particular in Eastern religions such as Hinduism. The fundamentalists' treatment of their religious sources is thereby characterized by their rejection of profane hermeneutical, philological and historical methods of exegesis.

(5) Millenarianism and messianism. Fundamentalist historiography envisions a miraculous culmination to world history, in which God finally triumphs over evil. "This is typified by promises of a quick redemption or rapture which are made either through millenarian (compensation for wrongs and suffering) or messianic (the Almighty Savior) models." 19 The concrete forms vary according to religious tradition and are more pronounced in the Abrahamic religions.

(6) Community of the elect. Fundamentalists view themselves as a divinely appointed community. Such consciousness of election can find expression in different concepts (e.g. "the holy remnant") and is closely related to the following point.

(7) Sharp demarcation. Generally, it can be observed that fundamentalists draw a strict dualistic distinction between their own circle of the elect and everyone else - the reprobate remainder (see point 3 above).

(8) Authoritarian organizational structure. As a rule, membership in fundamentalist groups is voluntary and unbureaucratic, resulting principally in equality among the members. Despite this, fundamentalist forms of organization follow "the charismatic leadership principle" 20.

(9) Strict rules of conduct. Elaborate rules of conduct with respect to dress, partner selection, etc. ensure strong affective ties. Sinful behavior, meanwhile, is prohibited in detail: "Rules about drinking, sexuality, appropriate speech, and the discipline of children abound. Likewise, there is censorship of reading material, and close supervision and viewing practices. Dating, mate selection, and the like are strictly regulated." 21

The above nine characteristics are closely intertwined; however, the first feature of "reactivity" is fundamental: "Fundamentalist movements are essentially religious reactions. More precisely, they are militant, mobilized and defensive responses to modernity or to specific developments thereof."22 Consequently,

19 Ibid., p. 189.

20 Ibid., p. 190.

21 Marty / Appleby 1995, p. 408.

22 Grünschloß 2009, pp. $190 \mathrm{f}$. 
fundamentalists selectively seek recourse among "fundamental" pillars of tradition that, being absolutely true, provide a clear way out of the confusion engendered by a frightening crisis. At the same time, the attendant consciousness of election leads to a dualistic demarcation in respect to the outside world.

\section{Fundamentalism as a theological challenge}

\subsection{Theological areas of discussion}

Religious fundamentalism entails a theological challenge in various respects. Making no claim to comprehensiveness, we can outline the following points:

(1) Differentiated language use and a change of perspective. Given that the term "fundamentalism" is often used as a sweeping term to belittle other groups, the first, important challenge relates to the term's use with respect to other denominations and religions: from a theological and religious studies' perspective, there are a variety of reasons to ensure that other denominations and religions are not easily identified with fundamentalism; thus, it is important to distinguish, for example, between Islamic fundamentalism and Islam as thoroughly as one distinguishes between Protestant fundamentalism and Protestantism. At the same time, from the perspective of one's own religion, such emphatic distinctions should not offer immunity against criticism along the lines of "fundamentalist violence has nothing to do with my own religion". When it comes to one's own religion, in my view, one must engage in self-criticism and confront thereby the intersections between one's own religious tradition and fundamentalism.

(2) Justifying religious identity within an ideological and religious pluralism. This raises a cardinal question in the confrontation with fundamentalism, which is also a key issue for religious education: religious identity requires a foundation. While fundamentalism offers precisely such a foundation, it does so at the expense of pluralism. The lure of fundamentalism lies in its ability to offer a Biblical foundation for one's identity during confusing times - this, however, comes at the price of having to demarcate clear boundaries in respect to others.

We can oppose such a problematic pursuit of singularity and segregation with the Christian-theological concept of the "pluralistic foundation of the Christian religion":

When one looks [...] at the foundations of the Christian discourse about God - that is, at the canon of Old and New Testament writings - one is confronted with an utterly heterogeneous picture of well over a thousand years of textual history - or, to formulate this positively, a truly colorful abundance of voices, diverse in form and content, within which each in its own manner recounts the narrative of God in history. ${ }^{23}$

23 Wunderlich 1997, p. 108. 
(3) Religion and politics, as well as (4) theology and science. Both of these points are relatively closely tied to the understanding of Scripture that is discussed in more detail below. When it comes to the relationship between science and theology, it is evident that a literalist understanding of Genesis 1 as a putative scientific account of creation leads to an utterly different attitude towards the Big Bang and the theory of evolution, than that ensuing from an understanding of Genesis 1 as a poesy of creation, in which people living 2500-3000 years ago expressed their beliefs in God as a creator and sustainer through the medium of their contemporary worldviews. Similarly, if we consider the historical context of political statements found in Biblical texts (e.g. patriarchalism), we will be able to draw important distinctions about religion and politics quite independently of frameworks like the two kingdoms doctrine. Since a comprehensive theological analysis of the foregoing points is beyond the scope of the present article, the following section focuses on the pivotal issue of how Scripture is understood, as this has played a seminal role in Christian fundamentalism since its origin.

\subsection{Biblical inerrancy as a seminal challenge}

The International Council on Biblical Inerrancy was founded in Chicago in 1977. The result of the council's first international summit conference (held in 1978) was the Chicago Statement on Biblical Inerrancy, within which point 4 of "A Short Statement" asserts the following:

Being wholly and verbally God-given, Scripture is without error or fault in all its teaching, no less in what it states about God's acts in creation, about the events of world history, and about its own literary origins under God, than in its witness to God's saving grace in individual lives. ${ }^{24}$

Why are fundamentalists so deeply committed to Biblical inerrancy, and why do they respond so strongly when inerrancy is questioned? Perhaps, when one considers the socio-psychological reasons enumerated above, these questions may not seem too surprising, and yet they gain new urgency if one considers the possible objection of fundamentalists: "It may be that I am religiously unsettled by modernity. But what matters is whether I am right in appealing to Biblical inerrancy or not." Thus, besides merely explaining the sociological or psychological causes for the claim of Biblical inerrancy, we should also accord the claim itself a theological assessment. It must be remembered that Biblical inerrancy has a long theological tradition and serves to buttress one of the foundations of Protestant theology - i.e. sola scriptura ("by Scripture alone"). According to Martin Luther, the authority of Scripture lies in the fact that Scripture requires no

24 International Council on Biblical Inerrancy 1978. 
elucidation either by a tradition or a magisterium. Likewise, according to the "Formula of Concord", the Lutheran statement of faith of 1577, it is not the magisterium but Scripture alone that is the judge, the canon, the rule and the touchstone of doctrine. Here, it is worth looking further back in history. ${ }^{25}$ For, the doctrine of Scripture espoused by fundamentalists largely corresponds to that of older Protestant orthodoxy, which in the late $16^{\text {th }}$ century was a leading school of theology: the authority of Scripture is founded on the fact that God is the proper author of Scripture. Scripture is a dictation of the Holy Spirit - in which process, humans served as the nibs or the hands of the Holy Spirit. It follows therefore that there can be no human error in Scripture. Although we cannot justify this in greater detail here, the divergence expressed herein from Luther's doctrine of Scripture is quite remarkable. Conversely, the proximity to the fundamentalist doctrine of Scripture is unmistakable: the Bible is God's Word, literally and inerrantly.

At this point it becomes clear why fundamentalists so decidedly reject the historical-critical method: in its framework, the Bible is treated no differently than any other historical work of human literature. To put it bluntly, it treats the Bible as the word of humans. Over time, the findings of historical criticism led to a substantial dismantling of the orthodox doctrine of scripture. Indeed, as scholarship elaborated the historical contexts surrounding Biblical statements, NeoProtestantism increasingly abandoned the doctrines of verbal and dynamic inspiration, if not the larger doctrine of inspiration in general. In doing so, however, the authority of Scripture was also increasingly undermined. Wolfhart Pannenberg notes to this that "resolving the issue of the doctrine of Scripture is the basic crisis of contemporary Protestant theology." 26 Here too, as in a litmus test, the theological confrontation with fundamentalism indicates a basic crisis of Protestantism. Nevertheless, insisting on Biblical inerrancy offers no way out of this quandary. To the contrary, the assertion of Biblical inerrancy is problematic for a variety of reasons: $:^{27}$

(1) It leads to the equivalence of all Biblical statements: the new commandment becomes equivalent to "[the Jews, M. R.] displease God and are hostile to everyone" (1 Thess 2:15 New International Version) or to "do not allow a sorceress to live" (Exodus 22:18 NIV).

(2) Biblical inerrancy leads to futile apologias: for example, fundamentalists have to justify that Elisha's iron axehead actually floated in the Jordan River (2 Kings 6:6 NIV).

(3) It contributes to the perversion of the certainty of and security in faith. This pursuit of false security manifests itself as in the following statement: "If the Bible

25 Joest 1988, pp. $155 \mathrm{ff}$.

26 Pannenberg 1967, p. 13.

27 Further arguments (using textual criticism, canon history, Bible theology, semiotics, reception theory, ethics) can be found in Alkier 2005, pp. 191-223. 
is wrong at any arbitrary point, then who can guarantee that it is also not wrong in its statements of salvation?" In opposition to this, it should be noted that there is no security, but only one's certainty of faith that the Bible is a testament of God's Word. In the words of Friedrich Schleiermacher, "The esteem of the Holy Scriptures cannot justify faith in Christ; to the contrary, the latter is a precondition to granting the Scriptures any special esteem."28

(4) Finally, viewing the Bible as an inerrant text shifts the foundation of faith from faith in Jesus Christ to faith in Biblical inerrancy - in contradiction to John 1 , where God's Word is incarnated through Jesus Christ, instead of being inscribed in Scripture.

In summary, the above suggests that the doctrine of Biblical inerrancy may be engaged as more than simply an expression of a "modern" uncertainty. In fact, we see that the claim of Biblical inerrancy does not hold up even from the theological perspective. Nevertheless, as simple as it may seem to challenge the fundamentalist doctrine of Scripture, just so difficult it is to offer an answer to fundamentalists who point to Protestantism's crisis of the Scripture principle. ${ }^{29}$ One strength of fundamentalists is that, here, they offer simplified and concise reductions in complexity. This is precisely what makes fundamentalism alluring within the complexity of postmodernity.

\section{Religious educational perspectives}

\subsection{Fundamentalism as an epochal key problem}

Wolfgang Klafki introduced the concept of "epochal key problem" to the discourse of education, employing the concept to provide a very specific answer to the question of which canonical educational content contributes to general education. Klafki's thesis is as follows:

\footnotetext{
28 Schleiermacher $1830-31, \S 128$.

29 The relevance of Scripture in terms of historical influence can, in my view, be justified through the following claim of Joest's: "The canonical significance of the Biblical tradition remains fundamentally rooted in the historical experience of representing Jesus Christ as well as in this experience's inspirational and critical work in the life of the Church, which originates from and is predicated on the fact of these writings' existence through to the present day; and this is further joined with the understanding that these writings provide, in the form of precipitate, the oldest Christian promulgation of the original, historically-mediated access to the life of Jesus Christ and the faith that he awakened" (Joest 1988, p. 172).
} 
In this respect, general education means the gaining of a historically mediated awareness of the central problems of the present and (insofar as it can be foreseen) the future, insight into our common responsibility before these problems and the readiness to collaborate in solving them. ${ }^{30}$

Through the foregoing example of early fundamentalism in the United States, we have seen that a basic feature of fundamentalism is "modern antimodernism". The very concept of "modern antimodernism" signals an epochal character and serves as an indication that we must reflect on fundamentalism on the same plane as we accord globalization and global education. ${ }^{31}$ The present societal and international significance of fundamentalist currents obtrudes itself by no means solely through extremist-terrorist forms, but equally through the unexpected resurgence of creationist ideas. And this clearly demonstrates the educational relevance of this topic, which is still anchored in inadequate teaching and educational plans and receives only peripheral treatment in the discourse of religious education. $^{32}$

\subsection{Reflexive questions for religious teachers}

A particular challenge to religious education in its engagement with this topic is that fundamentalism represents by no means primarily a knowledge question, but is entwined with problems of attitude or prejudice: on the one hand, we cannot expect fundamentalist-oriented youth to change their attitude as a result of cognitive information provided by a lesson on the subject of fundamentalism. Given the underlying "modern" insecurities, the basic need for a clear orientation is unambiguous. On the other hand, non-fundamentalist-oriented youth as well as religious teachers cannot rashly dismiss fundamentalist-oriented people, without first giving serious consideration to their motives and the general "appeal" of fundamentalist groups amidst the confusion of (post-)modernity.

When it comes to attitudes, an essential first step for teachers is to reflect on their own attitudes about (post-)modern pluralism and fundamentalism and to put themselves in different positions. In view of this, what follows are reflexive questions that have been developed by Hans-Georg Ziebertz:

$30 \quad$ Klafki 2007, p. 56.

31 For more on this, see Kim 2015.

32 Aside from a few brief and rather general articles in encyclopedias and handbooks, there are only sporadic booklets (e. g. Evangelische Erzieher 1995 H. 4; abstract 2010 H. 1), essays (e.g. Streib 2001) and a recently published monograph (Eppler 2015) on the topic. Here, the publications of Schweitzer 2015, Büttner 2010, and Heimbrock 2005 deserve special mention. 
- How do I perceive, cognitively and emotionally, the diversity of opinions and ways of life in our society, and how do I respond to it?

- How do I perceive pluralism in religious communities, [...] and how do I respond to it?

- Can I personally tolerate different positions, even if they suggest basic life attitudes that I cannot subscribe to?

Indication: Awareness of one's own (defensive) attitude towards the experience of pluralism. [...]

- How do I think about fundamentalism (i. e. the absolute prescription of a single group's position for everyone), both in the context of society and religion?

- How do I think about it when I myself belong to a majority group that feels threatened by a fundamentalist minority?

- How do I think about it when I sympathize with the assertion of a minority position to the detriment of a majority, or when I participate in such an assertion?

Indications: Awareness of one's ambivalence toward majorities or minorities as a criterion for the quality of a position; awareness of the 'threat potential' of a fundamentalist response to pluralism; awareness of the improbability of being able to reduce pluralism to unity. [...]

- What do I think of the position: "All opinions have equal value?"

- Where do I stand in respect to the statement: "To each his own?"

- Do I find that tolerance of others' opinions and actions is paramount? Or are there limits?

Indications: Awareness of the need to critically differentiate between self-interest and common good when applying the concept of tolerance; awareness of the difficulty of effecting diversity for its own sake. ${ }^{33}$

Reflexive questions like these are necessary to such a sensitive topic, as they enable teachers to become aware of their own attitudes and behave appropriately toward fundamentalist-oriented pupils. Teaching experience shows that such students "shut down" relatively quickly when they are marginalized by critical remarks. ${ }^{34}$

\subsection{Fundamentalism as a key topic for religious education: Concluding theses}

Before presenting the three concluding theses, it should be observed that this area requires further religious educational research. Particularly lacking are empirical studies on the dissemination of fundamentalist attitudes among adolescents, as well as relevant intervention studies that examine the effects of teaching strategies aimed at fundamentalist attitudes. ${ }^{35}$ Accordingly, the following theses have a provisional character:

33 Ziebertz 1996, pp. $31 \mathrm{f}$.

34 I am indebted to Rudolf Tammeus for this observation.

35 Streib (2001) offers an exception to this. 
(1) A treatment of fundamentalism in the context of Christian religious education should not focus on Islamic fundamentalism, but on a discussion of the "original" Protestant fundamentalism. Historical events such as the Scopes Monkey Trial are ideally suited to exemplify the problematic consequences of a literalist understanding of Scripture. ${ }^{36}$ Furthermore, disputes over creationism are today as current as they have ever been; the misunderstanding of Genesis 1 as a "factual account" of creation is still disseminated to young people. The problem here is that the creation poesy of Genesis 1, on the one hand, and scientific theories of world and life formation, on the other hand, express different ways of approaching the world and, accordingly, different rationalities. This brings us to Thesis 1: fundamentalism is a key topic for religious education because it exemplifies the distinctiveness and legitimacy of different rationalities and ways of approaching the world. Though we cannot explore it in more detail here, this thesis is derived from the educational theory of Jürgen Baumert (2002), who distinguishes between different rationalities and approaches to the world.

(2) The instruction should not limit itself to a critique of fundamentalism. Instead, fundamentalism should be addressed as an indicator of Protestantism's crisis of the Scripture principle, which is itself documented by young students' attitudes towards the Bible. Accordingly, Thesis 2 is as follows: fundamentalism is a key topic for religious education because it exemplifies the ways of considering the role and authority of the Bible or, more specifically, the Holy Scriptures.

(3) Basically, fundamentalism should be understood as a reaction to "modern" insecurities. In this sense, its advantages and disadvantages can be engaged in the light of an oppositional alternative to "utter relativism". In positive terms - in accordance with "Winning Religious Orientation", the recent memorandum of the Evangelical Church in Germany - this entails a pursuit of the reasonable educational goal of the "capacity for plurality" 37 . At that, this "capacity for plurality" does not mean "a dilution or a relativization of faith. Rather, it offers an approach by which religiously and ideologically pluralistic situations can be handled reasonably within the framework of one's own faith." ${ }^{38}$ Ultimately, religious education seeks to form a religious identity that lies between the two extremes of "relativism that emanates from the principle that all ways of faith are

36 When it comes to the literalist understanding of Scripture, it is worth considering studies in developmental psychology: James Fowler speaks of the "mythical-literal" faith in the second stage of faith development. A literalist faith is thus indicative of a specific developmental phase in the larger structure of faith. For this reason, a dispute of the fundamentalists' literalist understanding of Scripture is recommended only towards the end of the junior level of secondary school.

37 "Religiöse Orientierung gewinnen" (Church Office of the Evangelical Church in Germany 2014).

38 Schweitzer 2015, p. 25. 
equally valid" and "fundamentalism, which absolutizes its own convictions" 39 . In this sense, Thesis 3 is as follows: fundamentalism is a key topic for religious education because a critical analysis of fundamentalism can aid in pursuing the educational goal of the "capacity for plurality".

\section{References}

Alkier, Stefan: "Die Bibel ist nicht vom Himmel gefallen. Sechs bibelwissenschaftliche Argumente gegen den christlichen Fundamentalismus", in: Alkier, Stefan / Deuser, Hermann / Linde, Gesche (eds.): Religiöser Fundamentalismus. Analysen und Kritiken. Tübingen 2005, pp. 191-223.

Brocker, Manfred : Protest - Anpassung - Etablierung. Die Christliche Rechte im politischen System der USA. New York 2004.

Büttner, Gerhard: Verständigungen über das Heilige. Wie sollen Schule und Religionsunterricht mit "fundamentalistischen" Phänomenen umgehen? Unpublished manuscript 2010, pp. 13-15.

Eppler, Wilhelm (ed.): Fundamentalismus als religionspädagogische Herausforderung. Göttingen 2015.

Geldbach, Erich: "Der frühe Fundamentalismus", in: Dressler, Bernhard / Ohlemacher, Jörg / Stolz, Fritz (eds.): Fundamentalistische Jugendkultur. Loccum 1995, pp. 60-80.

Grünschloß, Andreas: "Was ist 'Fundamentalismus'? Zur Bestimmung von Begriff und Gegenstand aus religionswissenschaftlicher Sicht”, in: Fuldaer Hefte 39. Berlin 2009, pp. 163-196.

Heimbrock, Hans-Günter: "Wahrheit - Lebensform - Subjekt. Praktisch-theologische Anmerkungen zu christlichen Fundamentalismen", in: Alkier, Stefan / Deuser, Hermann / Linde, Gesche (eds.): Religiöser Fundamentalismus. Analysen und Kritiken. Tübingen 2005, pp. 27-44.

Hochgeschwender, Michael: Amerikanische Religion. Evangelikalismus, Pfingstlertum und Fundamentalismus. Frankfurt am Main 2007.

International Council on Biblical Inerrancy, The Chicago statement on Biblical inerrancy, 1978, available at Dallas Theological Seminary's Turpin Library Web site: http://library.dts.edu/Pages/TL/Special/ICBI_1.pdf [29.01.2016].

Jewett, Robert / Wangerin, Ole: Mission und Verführung. Amerikas religiöser Weg in vier Jahrhunderten. Göttingen 2008.

Joest, Wilfried: Fundamentaltheologie. Theologische Grundlagen- und Methodenprobleme. Stuttgart 1988.

Kim, Hyun-Sook: "Seeking critical hope in a global age: religious education in a global perspective”, in: Religious Education (110/3) 2015, pp. 311-328.

Klafki, Wolfgang: Neue Studien zur Bildungstheorie und Didaktik. Zeitgemäße Allgemeinbildung und kritisch-konstruktive Didaktik. Weinheim 2007.

39 Ibid. 
Küenzlen, Gottfried: "Feste Burgen: Protestantischer Fundamentalismus und die säkulare Kultur der Moderne", in: Aus Politik und Zeitgeschichte (Beilage zur Wochenzeitung Das Parlament), B (33) 1992, pp. 3-10.

Küenzlen, Gottfried: "Fundamentalismus und die säkulare Kultur der Moderne", in: Hemminger, Hansjörg (ed.): Fundamentalismus in der verweltlichten Kultur. Stuttgart 1991, pp. 196-221.

Marty, Martin E. / Appleby, R. Scott (eds.): Fundamentalisms Comprehended. Chicago 1995.

Moltmann, Jürgen: "Fundamentalismus und Moderne", in: Concilium (28/3) 1992, pp. 269-273.

Niagara Bible Conference, (n. d.), available at Wikipedia: https://en.wikipedia.org/wiki/ Niagara_Bible_Conference [27.12.2015].

Pannenberg, Wolfhart: Grundfragen systematischer Theologie. Gesammelte Aufsätze. Göttingen 1967.

Reich, Jutta: "Twentieth Century Reformation”. Dynamischer Fundamentalismus nach Geschichte und Erscheinung. Marburg 1969.

Riesebrodt, Martin: "Was ist religiöser Fundamentalismus?", in: Six, Clemens / Riesebrodt, Martin / Haas, Sigfried (eds.): Religiöser Fundamentalismus. Vom Kolonialismus zur Globalisierung (= Querschnitte 16). Innsbruck 2005, pp. 13-32.

Riesebrodt, Martin: Fundamentalismus als patriarchalische Protestbewegung. Tübingen 1990.

Rothgangel, Martin: "Fundamentalismus", in: Lachmann, Rainer / Rothgangel, Martin / Schröder, Bernd (eds.): Christentum und Religionen elementar. Lebensweltlich - theologisch-didaktisch (= Theologie für Lehrerinnen und Lehrer 5). Göttingen 2010, pp. 343-361.

Schleiermacher, Friedrich D. E.: Der christliche Glaube. Berlin 1960 [1830-31].

Schweitzer, Friedrich: "Fundamental, nicht fundamentalistisch - Wege einer religiösen Erziehung jenseits von Relativismus und Fundamentalismus", in: Eppler, Wilhelm (ed.): Fundamentalismus als religionspädagogische Herausforderung. Göttingen 2015, pp. 13-30.

Streib, Heinz: "Fundamentalism as a challenge for religious education", in: Religious education (96/2) 2001, pp. 227-244.

Tibi, Bassam: Die islamische Herausforderung. Religion und Politik im Europa des 21. Jahrhunderts. Darmstadt 2008.

Victor, Barbara: Beten im Oval Office. Christlicher Fundamentalismus in den USA und die internationale Politik. München 2005.

Wunderlich, Reinhard: Pluralität als religionspädagogische Herausforderung (Arbeiten zur Religionspädagogik 14). Göttingen 1997.

Ziebertz, Hans-Georg: "Prinzipielle religionsdidaktische Grundregeln II", in: Groß, Engelbert / König, Klaus (eds.): Religionsdidaktik in Grundregeln. Leitfaden für den Religionsunterricht. Regensburg 1996, pp. 30-48. 